\title{
Levels of Soluble Cell Adhesion Molecules in Patients With Angiographically Defined Coronary Atherosclerosis
}

\author{
Keijiro Saku, MD; Bo Zhang, PhD; Takao Ohta, MD*; Kazuyuki Shirai, MD; \\ Yoshihiro Tsuchiya, MD; Kikuo Arakawa, MD
}

\begin{abstract}
Adhesion molecules on the endothelial cell membrane play an important role in the pathogenesis of atherosclerosis. Levels of soluble forms of cell adhesion molecules are reportedly elevated in patients with peripheral artery vessel disease and in patients with an atherosclerotic aorta. The present study investigated the association of serum levels of soluble vascular cell adhesion molecule 1 (sVCAM-1), soluble intercellular adhesion molecule 1 (sICAM-1), and soluble P-selectin (sP-selectin) with coronary heart disease (CHD) and the extent of coronary atherosclerosis, and examined the influence of serum levels of lipids, lipoproteins and apolipoproteins (apo) in subjects with $(n=52, M / F: 43 / 9)$ and without (controls, $n=40, M / F: 25 / 15)$ angiographically proven coronary atherosclerosis. After controlling for age and gender, levels of sVCAM-1 (least squares mean \pm std error: $565 \pm 36$ $\mathrm{ng} / \mathrm{ml}$ vs $540 \pm 41 \mathrm{ng} / \mathrm{ml}$, ns), sICAM-1 $(261 \pm 17 \mathrm{ng} / \mathrm{ml}$ vs $247 \pm 19 \mathrm{ng} / \mathrm{ml}$, ns $)$, and sP-selectin $(142 \pm 8 \mathrm{ng} / \mathrm{ml}$ vs $149 \pm 10 \mathrm{ng} / \mathrm{ml}, \mathrm{ns}$ ) in patients with coronary atherosclerosis were not different from those in controls, as assessed by an analysis of covariance. After also adjusting for body mass index, hypertension, diabetes mellitus, and smoking by a multiple logistic function analysis, the association of sVCAM-1, sICAM-1, and sP-selectin with CHD was still not significant. Levels of sVCAM-1, sICAM-1, and sP-selectin were also not related to the extent of coronary atherosclerosis as judged by the number of stenosed vessels. However, inverse $(\mathrm{p}<0.05)$ relationships were observed between sVCAMs and serum levels of HDL3-cholesterol, apo A-II, and lipoprotein containing apo A-I and A-II, between sICAMs and levels of apo A-II and Lp A-I/A-II (Lp A-I/A-II), and between sPselectin and lipoprotein containing only apo A-I. In conclusion, serum levels of soluble VCAM-1, ICAM-1, and P-selectin were not related to CHD or the extent of coronary atherosclerosis, but were inversely related to serum levels of high-density lipoprotein-related lipoproteins. (Jpn Circ J 1999; 63: 19-24)
\end{abstract}

Key Words: Atherosclerosis; Coronary angiography; High-density lipoprotein; Soluble cell adhesion molecules

$\mathbf{T}$ he adhesion of leukocytes to endothelial cells and their transendothelial migration are critical early events in the pathogenesis of atherosclerosis ${ }^{1}$ and are mediated by adhesion molecules on the endothelial cell membrane that mainly belong to 2 protein families: the selectins and adhesion molecules of the immunoglobulin superfamily? The expression of P-selectin (a member of the first group), and of both vascular cell adhesion molecule 1 (VCAM-1) and intercellular adhesion molecule 1 (ICAM1) (members of the second group), has been demonstrated in various cell types forming the atherosclerotic plaque; that is, endothelial cells, vascular smooth muscle cells, and macrophages ${ }^{3-8}$ Soluble forms of adhesion molecules are probably generated by cleavage at a site close to membrane insertion? The amount of soluble ICAM-1 has been demonstrated to be directly correlated with the surface expression of ICAM-1 in endothelial cells in culture ${ }^{10}$ and a correlation between soluble VCAM-1 and VCAM-1 mRNA

(Received July 2, 1998; revised manuscript received August 31, 1998; accepted September 24, 1998)

Department of Internal Medicine, Fukuoka University School of Medicine, Fukuoka and $*$ Department of Pediatrics, Faculty of Medicine, University of the Ryukyus, Okinawa, Japan

\#Part of this work was presented at the 62th Annual Scientific Session, Japanese Circulation Society, Tokyo, Japan, on March 26th, 1998

Mailing address: Keijiro Saku, MD, PhD, FACP, Department of Internal Medicine, Fukuoka University School of Medicine, 7-45-1 Nanakuma Jonan-ku, Fukuoka 814-0180, Japan. E-mail: hh035399@ msat.fukuoka-u.ac.jp expression in human atherosclerotic aorta has also been reported 11

Several reports support the notion that the serum levels of soluble adhesion molecules may be useful for providing information on atherosclerotic lesions ${ }^{1-14}$ Serum levels of soluble P-selectin and ICAM-1 were elevated in patients with peripheral artery vessel disease (pAVD) ${ }^{13}$ and soluble VCAM-1 levels were elevated in patients with an atherosclerotic aorta, 11 compared with those in asymptomatic control subjects. Levels of soluble VCAM-1 and ICAM1 were also elevated in patients with severe hyperlipidemia, in whom advanced atherosclerosis can be expected, and in whom lipid-lowering drugs did not affect the levels of soluble VCAM-1 and ICAM-1!4 Furthermore, in patients with pAVD, circulating VCAM-1 correlated with the extent of atherosclerosis as defined by the mean internal vessel surface area of the abdominal aorta and pelvic and leg arteries! ${ }^{2}$

In the present study, we studied the serum levels of soluble VCAM-1, ICAM-1, and P-selectin in patients with and without (controls) angiographically defined coronary atherosclerosis. We examined the association of the levels of these soluble adhesion molecules with coronary heart disease (CHD) and the severity of coronary atherosclerosis as judged by the number of stenosed coronary arteries, and the influence of serum levels of lipids and lipoproteins on the levels of these soluble adhesion molecules. To the best of our knowledge, this is the first report of the detailed association between circulating cell adhesion molecules 

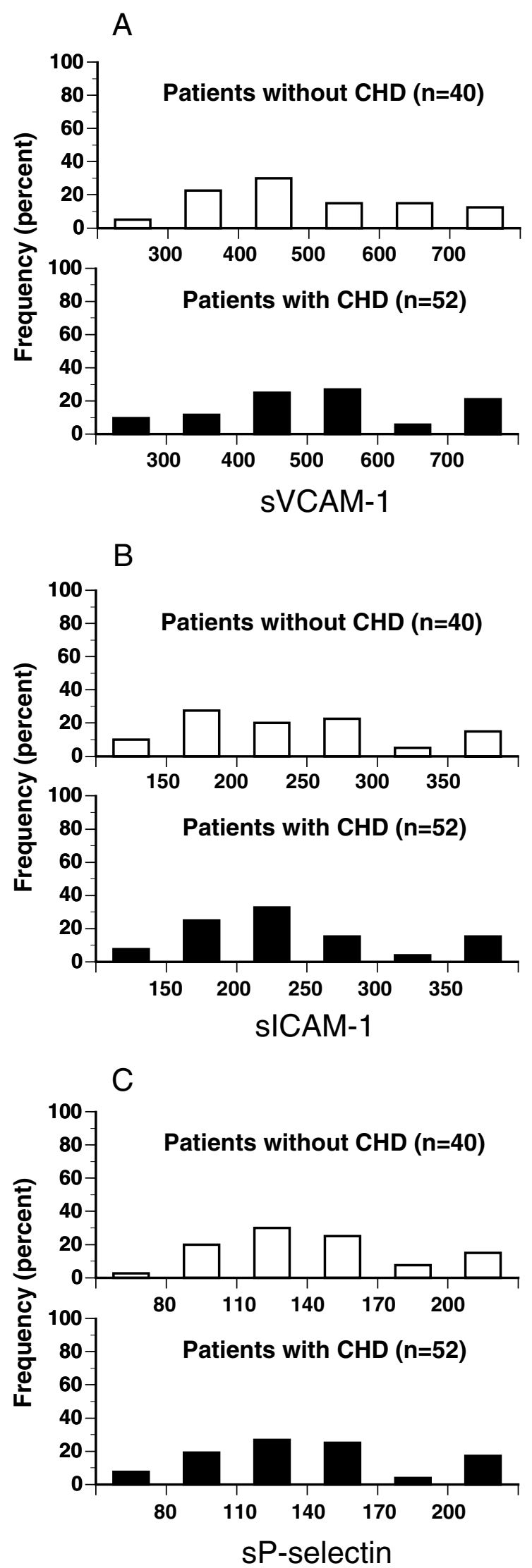

Fig 1. Frequency distributions of the levels of (A) soluble vascular cell adhesion molecule 1 (sVCAM-1), (B) soluble intercellular adhesion molecule 1 (sICAM-1), and (C) P-selectin in patients with (ם) and without $(\square)$ coronary heart disease (CHD). and their relation to lipoproteins and apolipoproteins in a clinical study.

\section{Methods}

\section{Patients}

The study population included 92 patients who underwent diagnostic coronary angiography for suspected or known CHD or for other reasons (mostly atypical chest pain) at Fukuoka University Hospital from 1994 to 1996. The study was approved by the Ethics Committee of Fukuoka University Hospital and informed consent was obtained from each patient. Controls (without CHD) were defined as those with less than $25 \%$ luminal narrowing, and CHD patients were those who had 1,2 or 3 stenosed $(>50 \%$ luminal narrowing) epicardial coronary arteries. Patients with vasospastic angina were excluded from the controls and none of the controls had myocardial infarction (MI). As patients with acute MI (within 3 weeks after onset) have been shown to have increased plasma levels of soluble ICAM-15 and P-selectin ${ }^{16}$, they were excluded from the study. Patients with heart failure (Killip Class $\geq 2$ after MI), aortitis treated by prednisolone, hepatic dysfunction (viral and non-viral, transaminases more than 3 times the normal value), or uncontrollable diabetes mellitus (DM) were also excluded from the study. Patients with systolic or diastolic blood pressure $>160 \mathrm{mmHg}$ or $95 \mathrm{mmHg}$, respectively, or who were under anti-hypertensive treatment were considered to have hypertension (HT). Patients under treatment for DM and/or with symptoms of DM and a fasting glucose concentration $\geq 126 \mathrm{mg} / \mathrm{dl}$ were considered to have DM. Otherwise, the results of a 75-g glucose tolerance test were used to diagnose DM.

\section{Coronary Angiography}

Coronary angiography was performed by the Judkins technique ${ }^{17}$ with $5 \mathrm{~F}$ catheters, and recorded on Kodak 35 $\mathrm{mm}$ cinefilm at a rate of 30 frames/s. Coronary arteries were divided into 15 segments, according to the classification of the American Heart Association Grading Committee. Coronary artery segments for reference were carefully selected by 2 expert cardiologists on the basis of smooth luminal borders and the absence of stenotic changes. The presence of stenosis was determined using a computer-assisted coronary angiography analysis system (Mipron 1; Kontron Co) after the direct intracoronary injection of isosorbide dinitrate (ISDN) $(2.5 \mathrm{mg} / 5 \mathrm{ml}$ solution). One minute after the injection of ISDN through the Judkins catheter over $20 \mathrm{~s}$, coronary angiography was performed from several projections over $7 \mathrm{~min}$, as described previously! ${ }^{18}$ Arterial stenosis that produced more than $50 \%$ luminal narrowing was considered significant.

Determination of Serum Lipids, Lipoproteins, Apolipoproteins, and Soluble Cell Adhesion Molecules

Blood was drawn in the morning after an overnight fast. Serum total cholesterol (TC), free cholesterol (FC), and triglyceride (TG) concentrations were determined enzymatically! ${ }^{19,20}$ High-density lipoprotein cholesterol (HDLC) was determined by the heparin $\mathrm{Ca}^{2+}$ precipitation method. ${ }^{21}$ HDL subfractions (HDL2 and HDL3) were separated by standard sequential preparative ultracentrifugation techniques. 22 Serum apolipoproteins (apo) A-I, A-II, B, CII, C-III, and E were determined by the turbidity 
immunoassay method ${ }^{23}$ Apo A-II levels play a major role in regulating the distribution of apo A-I among the HDL subclasses Lp A-I (lipoprotein containing only apo A-I) and Lp A-I/A-II (lipoprotein containing both apo A-I and apo A-II) in humans ${ }^{24}$ LpA-I/A-II appears to have a fixed molar ratio of 3:2 for these apolipoproteins ${ }^{25,26}$ In our preliminary experiments, plasma concentrations of LpA-I isolated by immunoaffinity chromatography 27 correlated well with those of LpA-I calculated based on a fixed molar ratio of apoA-I to apoA-II $(n=30, r=0.91, p<0.001)$. Thus, we calculated the plasma concentrations of LpA-I and LpA-I/A-II in the present study.

Levels of sVCAM-1, sICAM-1 and sP-selectin were determined by monoclonal antibody-based enzyme-linked immunosorbent assays (R\&D Systems) using frozen serum samples. Briefly, all samples and controls were examined in duplicate, and the concentrations of the samples were determined by analyzing standards with known concentrations of recombinant adhesion molecules coincident with samples and plotting a curve of signal versus concentration. According to the commercial supplier, no cross-reactivity is observed between the aforementioned sCAMs. For all measurements in our laboratory, the interassay and intraassay coefficients of variation were less than $10 \%$ and $5 \%$, respectively, and blinded quality-control specimens were included in each assay.

\section{Statistical Analysis}

Statistical analysis was performed using the SAS Software Package (Version 6, Statistical Analysis System, SAS Institute Inc, Cary, NC, USA). Categorical variables (such as gender) and frequency distribution patterns between patients with and without CHD were compared by a Chi-square analysis. The distribution of continuous variables was examined by the Shapiro-Wilk test ${ }^{26}$ Differences between patients with and without CHD or among patients with 1-, 2-, and 3-vessel disease were examined by an analysis of variance (ANOVA). Comparisons of 1-vessel and 2- or 3-vessel disease patients were performed with the multiple comparison test of Dunnette ${ }^{28}$ Age and gender were adjusted for by an analysis of covariance (ANCOVA) ${ }^{28}$ The association between CHD and soluble adhesion molecules after controlling for age, gender, and potentially confounding variables was evaluated by a multiple logistic function analysis $2^{29}$ For all of the adjusted odds ratios, we calculated $95 \%$ confidence intervals (CI). For logistic parameter estimates, we showed the standard error. The influence of lipid parameters on levels of soluble adhesion molecules while controlling for age, gender, and body mass index (BMI) was examined by a covariance analysis using the General Linear Model procedure? 8 Results of the type II tests are given, where the effects of lipid variables on levels of sCAMs are adjusted for age, gender, and BMI. All p-values are 2-tailed. The significance level was considered to be $5 \%$ unless otherwise indicated.

\section{Results}

Table 1 shows the characteristics of patients with and without CHD (controls). There were significantly more males, HT, DM and smokers in patients with CHD than in the controls. Age and BMI were not significantly different between the 2 groups. Although all of the women except one were in menopause, none were receiving hormone
Table 1 Clinical Characteristics of the Study Subjects

\begin{tabular}{lcc}
\hline \hline & $\begin{array}{c}\text { Patients without CHD } \\
(n=40)\end{array}$ & $\begin{array}{c}\text { Patients with CHD } \\
(n=52)\end{array}$ \\
\hline Age (years) & $58 \pm 15$ & $64 \pm 12$ \\
Gender (male/female) & $25 / 15$ & $43 / 9^{*}$ \\
Body mass index $\left(\mathrm{kg} / \mathrm{m}^{2}\right)$ & $23.6 \pm 2.9$ & $23.6 \pm 2.8$ \\
Hypertension $(\%)$ & 35 & $60^{*}$ \\
Diabetes Mellitus $(\%)$ & 18 & $37^{*}$ \\
Smokers (\%) & 45 & $79^{*}$
\end{tabular}

$C H D$, coronary heart disease. Values are mean $\pm S D .{ }^{*} p<0.05$ vs patients without CHD.

Table 2 Age- and Gender-Adjusted Values of Soluble Cell Adhesion Molecules and Lipid Variables

\begin{tabular}{lcc}
\hline \hline & $\begin{array}{c}\text { Patients without CHD } \\
(\mathrm{n}=40)\end{array}$ & $\begin{array}{c}\text { Patients with CHD } \\
(\mathrm{n}=52)\end{array}$ \\
\hline HDL-C $(\mathrm{mg} / \mathrm{dl})$ & $45.3 \pm 2.3$ & $37.6 \pm 2.0^{*}$ \\
HDL2-C $(\mathrm{mg} / \mathrm{dl})$ & $32.6 \pm 1.9$ & $26.3 \pm 1.6^{*}$ \\
HDL3-C $(\mathrm{mg} / \mathrm{dl})$ & $16.6 \pm 0.6$ & $16.0 \pm 0.5$ \\
Apo A-I $(\mathrm{mg} / \mathrm{dl})$ & $117 \pm 4$ & $102 \pm 4^{*}$ \\
Apo A-II $(\mathrm{mg} / \mathrm{dl})$ & $28.1 \pm 1.0$ & $26.3 \pm 0.9$ \\
Apo B $(\mathrm{mg} / \mathrm{dl})$ & $97.0 \pm 4.1$ & $105.2 \pm 3.5$ \\
Apo C-II $(\mathrm{mg} / \mathrm{dl})$ & $3.1 \pm 0.3$ & $3.3 \pm 0.2$ \\
Apo C-III $(\mathrm{mg} / \mathrm{dl})$ & $7.9 \pm 0.4$ & $7.7 \pm 0.4$ \\
Apo E $(\mathrm{mg} / \mathrm{dl})$ & $4.7 \pm 0.2$ & $4.8 \pm 0.2$ \\
Lp A-I $(\mathrm{nmol} / \mathrm{ml})$ & $17.3 \pm 1.1$ & $13.5 \pm 0.9^{*}$ \\
Lp A-I/A-II $(\mathrm{nmol} / \mathrm{ml})$ & $24.2 \pm 0.9$ & $22.7 \pm 0.8$ \\
TC $(\mathrm{mg} / \mathrm{dl})$ & $203 \pm 8$ & $194 \pm 7$ \\
TG $(\mathrm{mg} / \mathrm{dl})$ & $108 \pm 8$ & $125 \pm 7$ \\
FC $(\mathrm{mg} / \mathrm{dl})$ & $47.9 \pm 1.5$ & $50.5 \pm 1.3$ \\
LDL-C $(\mathrm{mg} / \mathrm{dl})$ & $136 \pm 8$ & $131 \pm 7$ \\
sVCAM- $1(\mathrm{ng} / \mathrm{ml})$ & $540 \pm 41$ & $565 \pm 36$ \\
P-selectin $(\mathrm{ng} / \mathrm{ml})$ & $149 \pm 10$ & $142 \pm 8$ \\
sICAM- $-1(\mathrm{ng} / \mathrm{ml})$ & $247 \pm 19$ & $261 \pm 17$ \\
\hline
\end{tabular}

HDL-C, high density lipoprotein cholesterol; Apo, apolipoprotein; TC, total cholesterol; TG, triglyceride; $L D L-C$, low density lipoprotein cholesterol; FC, free cholesterol; Lp A-I, lipoprotein containing only apo A-I; Lp A-I/A-II, lipoprotein containing both apo A-I and apo A-II; sVCAM-1, soluble vascular adhesion molecule 1; sICAM-1, soluble intercellular adhesion molecule 1.

Data are presented as least-square means \pm standard error.

${ }^{*} p<0.05$ v patients without $C H D$, as assessed by an analysis of variance.

Table 3 Multiple Logistic Function Analysis of the Association Between Soluble Adhesion Molecules and Coronary Heart Disease, after Considering Age, Body Mass Index, Gender, Hypertension, Diabetes Mellitus and Smoking

\begin{tabular}{lccc}
\hline \hline $\begin{array}{l}\text { Variables included } \\
\text { in the model }\end{array}$ & $\begin{array}{c}\text { Parameter estimate } \\
\pm \text { standard error }\end{array}$ & $\begin{array}{c}\text { Wald Chi- } \\
\text { square }\end{array}$ & $\begin{array}{c}\text { Odds ratio }(95 \% \\
\text { confidence interval) }\end{array}$ \\
\hline sVCAM-1 & $0.60 \pm 0.51$ & 1.43 & $1.83(0.68,4.93)$ \\
sICAM-1 & $-0.34 \pm 0.48$ & 0.48 & $0.71(0.28,1.85)$ \\
P-selectin & $-0.14 \pm 0.49$ & 0.08 & $0.87(0.33,2.28)$ \\
Age & $0.12 \pm 0.52$ & 0.05 & $1.12(0.41,3.10)$ \\
Body mass index & $-0.13 \pm 0.51$ & 0.07 & $0.88(0.32,2.37)$ \\
Gender & $-0.55 \pm 0.66$ & 0.70 & $0.58(0.16,2.09)$ \\
Hypertension & $0.86 \pm 0.51$ & 2.85 & $2.36(0.87,6.39)$ \\
Diabetes mellitus & $0.59 \pm 0.58$ & 1.01 & $1.80(0.57,5.64)$ \\
Smoking & $1.15 \pm 0.58$ & $3.87 *$ & $3.16(1.00,9.92)$ \\
\hline
\end{tabular}

${ }^{*} p<0.05$, significant association with CHD. see Table 2 for abbreviations.

replacement therapy.

Fig 1 shows the frequency distributions of soluble adhesion molecules in subjects with and without CHD. The distributions of sVCAM-1, sICAM-1, and sP-selectin levels in patients with CHD were not skewed toward higher 
levels compared with those in patients without CHD. Indeed, the distribution patterns of sVCAM-1, sICAM-1, and sP-selectin levels between the 2 groups were not different, as assessed by a Chi-square analysis.

Table 2 compares serum levels of lipids, lipoproteins, apolipoproteins, and soluble adhesion molecules in patients with and without $\mathrm{CHD}$ after controlling for age and gender. Serum levels of HDL-C, HDL2-C, apo A-I, and Lp A-I were significantly lower in patients with CHD than those without CHD. There were no significant differences in sVCAM-1, sICAM-1, and sP-selectin between patients with CHD and controls after adjusting for age and gender.

Table 3 shows the impact of BMI, HT, DM, and smoking

Table 4 Age- and Gender-Adjusted Values of Soluble Adhesion Molecules and Lipids in Patients With 1-, 2-, and 3-Vessel Coronary Stenosis

\begin{tabular}{lccc}
\hline \hline & $\begin{array}{c}\text { One vessel } \\
(n=23)\end{array}$ & $\begin{array}{c}\text { Two vessels } \\
(n=21)\end{array}$ & $\begin{array}{c}\text { Three vessels } \\
(n=8)\end{array}$ \\
\hline HDL-C $(\mathrm{mg} / \mathrm{dl})$ & $35.9 \pm 2.5$ & $43.6 \pm 2.7$ & $30.2 \pm 4.4$ \\
HDL2-C $(\mathrm{mg} / \mathrm{dl})$ & $24.9 \pm 2.1$ & $30.7 \pm 2.2$ & $21.5 \pm 3.6$ \\
HDL3-C $(\mathrm{mg} / \mathrm{dl})$ & $16.5 \pm 0.6$ & $16.7 \pm 0.6$ & $13.2 \pm 1.0^{*}$ \\
Apo A-I $(\mathrm{mg} / \mathrm{dl})$ & $101 \pm 5$ & $111 \pm 5$ & $88 \pm 8$ \\
Apo A-II $(\mathrm{mg} / \mathrm{dl})$ & $26.3 \pm 1.1$ & $26.4 \pm 1.2$ & $25.3 \pm 2.0$ \\
Apo B $(\mathrm{mg} / \mathrm{dl})$ & $112.1 \pm 4.7$ & $94.8 \pm 5.0^{*}$ & $103.1 \pm 8.2$ \\
Apo C-II $(\mathrm{mg} / \mathrm{dl})$ & $3.5 \pm 0.3$ & $3.0 \pm 0.3$ & $2.5 \pm 0.6$ \\
Apo C-III $(\mathrm{mg} / \mathrm{dl})$ & $7.8 \pm 0.5$ & $7.5 \pm 0.6$ & $7.1 \pm 0.9$ \\
Apo E $(\mathrm{mg} / \mathrm{dl})$ & $5.0 \pm 0.3$ & $4.5 \pm 0.3$ & $4.4 \pm 0.4$ \\
LpA-I $(\mathrm{nmol} / \mathrm{ml})$ & $13.0 \pm 1.2$ & $16.5 \pm 1.3$ & $9.4 \pm 2.1$ \\
LpA-I/A-II $(\mathrm{nmol} / \mathrm{ml})$ & $22.7 \pm 1.0$ & $22.7 \pm 1.0$ & $21.8 \pm 1.7$ \\
TC $(\mathrm{mg} / \mathrm{dl})$ & $204 \pm 6$ & $186 \pm 6$ & $180 \pm 10^{*}$ \\
TG $(\mathrm{mg} / \mathrm{dl})$ & $135 \pm 10$ & $101 \pm 10$ & $130 \pm 17$ \\
FC $(\mathrm{mg} / \mathrm{dl})$ & $52.5 \pm 1.6$ & $48.3 \pm 1.7$ & $48.0 \pm 2.8$ \\
LDL-C $(\mathrm{mg} / \mathrm{dl})$ & $141 \pm 5$ & $122 \pm 5 *$ & $124 \pm 9$ \\
sVCAM-1 $(\mathrm{ng} / \mathrm{ml})$ & $576 \pm 53$ & $580 \pm 56$ & $533 \pm 93$ \\
-selectin $(\mathrm{ng} / \mathrm{ml})$ & $135 \pm 11$ & $142 \pm 12$ & $159 \pm 19$ \\
sICAM- $1(\mathrm{ng} / \mathrm{ml})$ & $287 \pm 29$ & $252 \pm 30$ & $220 \pm 50$ \\
& & &
\end{tabular}

$H D L-C$, high density lipoprotein cholesterol; Apo, apolipoprotein; TC, total cholesterol; $T G$, triglyceride; $L D L-C$, low density lipoprotein cholesterol; FC, free cholesterol; Lp A-I, lipoprotein containing only apo $A-I ; \quad L p$ A-I/A-II, lipoprotein containing both apo A-I and apo A-II; sVCAM-1, soluble vascular adhesion molecule 1; sICAM-1, soluble intercellular adhesion molecule 1.

Data are presented as least-squares means \pm standard error.

${ }^{*} p<0.05$, vs patients without $C H D$, assessed by an analysis of variance. on the association between levels of soluble adhesion molecules and CHD. A multiple logistic function analysis showed a significant association only between smoking status and CHD. Levels of SVCAM-1, sICAM-1, and SPselectin were not associated with CHD after controlling for age, gender, BMI, HT, DM, and smoking.

Table 4 compares serum levels of lipids, lipoproteins, apoproteins, and soluble adhesion molecules among patients with 1,2, and 3 involved vessels, after adjusting for age and gender. Although lower levels of HDL3-C and TC were observed in patients with 3-vessel disease and lower levels of apo B and low density lipoprotein-cholesterol (LDL-C) were observed in those with 2 stenosed vessels, other variables including sVCAM-1, sICAM-1, and $\mathrm{sP}$-selectin were not associated with the extent of coronary atherosclerosis as defined by the number of stenosed vessels.

Table 5 shows the effects of serum levels of lipids, lipoproteins, and apolipoproteins on soluble adhesion molecules after controlling for age, gender, and BMI, using a covariance analysis. As shown in Table 5, levels of sVCAM-1 were inversely $(\mathrm{p}<0.05)$ related to levels of HDL3-C, apo A-II, apo B, and Lp A-I/A-II; levels of sICAM-1 were inversely related $(\mathrm{p}<0.05)$ to levels of apo A-II and Lp A-I/A-II; and levels of sP-selectin were related to levels of Lp A-I.

\section{Discussion}

Our results showed that the levels of soluble VCAM-1, ICAM-1, and P-selectin were inversely related to serum levels of high-density lipoprotein-related lipoproteins in a group of patients who underwent coronary angiography for chest pain, which may suggest a relation between the extent of atheroma and levels of circulating cell adhesion molecules.

\section{Association Between Circulating Cell Adhesion Molecules and CHD}

Elevated levels of soluble adhesion molecules have been reported in patients with pAVD, 13,30 in patients with an atherosclerotic aorta, ${ }^{11}$ and in patients with severe hyperlipidemia! ${ }^{14}$ However, our results showed that the levels of

Table 5 Covariance Analysis of the Influence of Lipid Parameters on Soluble Adhesion Molecules after Considering Age, Gender and Body Mass Index

\begin{tabular}{|c|c|c|c|c|c|c|c|c|c|}
\hline & \multicolumn{3}{|c|}{ Soluble VCAM-1 } & \multicolumn{3}{|c|}{ Soluble ICAM-1 } & \multicolumn{3}{|c|}{$P$-selectin } \\
\hline & $\begin{array}{c}\text { Parameter estimates } \\
\text { (standard error) }\end{array}$ & $\begin{array}{c}\text { Type II sum } \\
\text { of squares }\end{array}$ & $F$ value & $\begin{array}{l}\text { Parameter estimates } \\
\text { (standard error) }\end{array}$ & $\begin{array}{l}\text { Type II sum } \\
\text { of squares }\end{array}$ & $F$ value & $\begin{array}{c}\text { Parameter estimates } \\
\text { (standard error) }\end{array}$ & $\begin{array}{l}\text { Type II sum } \\
\text { of squares }\end{array}$ & $F$ value \\
\hline$H D L-C$ & $-0.70(1.93)$ & 8248 & 0.13 & $-0.95(0.90)$ & 15228 & 1.10 & $-0.60(0.43)$ & 5993 & 1.89 \\
\hline$H D L_{2}-C$ & $0.13(2.38)$ & 191 & 0.003 & $-0.87(1.12)$ & 8431 & 0.61 & $-0.70(0.53)$ & 5507 & 1.73 \\
\hline$H D L_{3}-C$ & $-21.7(7.4)$ & 491150 & $8.56^{*}$ & $-3.85(3.63)$ & 15468 & 1.12 & $-0.64(1.76)$ & 421 & 0.13 \\
\hline Аро A-I & $-0.29(0.98)$ & 5641 & 0.09 & $-0.52(0.46)$ & 17856 & 1.30 & $-0.27(0.22)$ & 4948 & 1.55 \\
\hline Apo A-II & $-9.32(4.13)$ & 303716 & $5.10 *$ & $-4.18(1.95)$ & 60897 & $4.59 *$ & $0.32(0.96)$ & 349 & 0.11 \\
\hline Аро B & $-2.29(1.05)$ & 281693 & $4.71 *$ & $-0.18(0.51)$ & 1805 & 0.13 & $-0.24(0.24)$ & 3130 & 0.98 \\
\hline Aро C-II & $-33.2(16.7)$ & 237287 & 3.93 & $4.59(8.03)$ & 4556 & 0.33 & $4.28(3.85)$ & 3963 & 1.24 \\
\hline Аро C-III & $-12.7(10.3)$ & 93999 & 1.52 & $-3.18(4.87)$ & 5920 & 0.43 & $1.11(2.35)$ & 721 & 0.22 \\
\hline Apo $E$ & $-36.1(22.9)$ & 153068 & 2.50 & $3.60(10.9)$ & 1518 & 0.11 & $-1.53(5.26)$ & 274 & 0.08 \\
\hline$L p A-I$ & $5.75(4.08)$ & 122268 & 1.98 & $0.12(1.94)$ & 58 & 0.004 & $-1.98(0.91)$ & 14509 & $4.71 *$ \\
\hline$L p A-I / A-I I$ & $-10.8(4.8)$ & 303707 & $5.10 *$ & $-4.84(2.26)$ & 60899 & $4.59 *$ & $0.37(1.12)$ & 349 & 0.11 \\
\hline$T C$ & $-0.96(0.54)$ & 192434 & 3.16 & $-0.18(0.26)$ & 6969 & 0.50 & $0.03(0.12)$ & 158 & 0.05 \\
\hline$T G$ & $-0.35(0.54)$ & 26081 & 0.42 & $0.14(0.26)$ & 4113 & 0.30 & $0.17(0.12)$ & 6373 & 2.01 \\
\hline$F C$ & $-2.67(2.95)$ & 51103 & 0.81 & $0.69(1.40)$ & 3433 & 0.24 & $-0.45(0.67)$ & 1469 & 0.45 \\
\hline$L D L-C$ & $-0.92(0.57)$ & 161288 & 2.64 & $-0.15(0.27)$ & 4197 & 0.30 & $0.04(0.13)$ & 381 & 0.12 \\
\hline
\end{tabular}

sVCAM-1, soluble vascular cell adhesion molecule 1; sICAM-1, soluble intercellular adhesion molecule 1.

$* p<0.05$, probability of a larger F value for the Type II test, where the effect of the lipid variable is adjusted for those of age, gender and body mass index. 
sVCAM-1, sICAM-1, and sP-selectin in CHD patients and controls were similar after adjusting for age and gender (Table 2). The distribution patterns of soluble cell adhesion molecules were compared between patients with and without CHD to exclude the possible influence of distribution, because Hwang et al ${ }^{31}$ reported a skewed distribution for circulating ICAM-1 and VCAM-1, and our sample size was too small to determine the accurate distribution of the levels of soluble adhesion molecules. However, in our study, similar frequency distribution patterns were observed, as shown in Fig 1. After additionally controlling for BMI, HT, DM, and smoking in a multiple logistic function analysis, levels of soluble adhesion molecules were still not significantly associated with CHD (Table 3). These results agree with those of Frijns et al ${ }^{32}$ who found no difference in SCAM or SVAM in carotid atherosclerosis. Hwang et al reported that plasma levels of ICAM-1 and Eselectin may serve as molecular markers for atherosclerosis and $\mathrm{CHD},{ }^{31}$ while Ridker et $\mathrm{al}^{33}$ showed that the risk of MI associated with raised concentrations of sICAM-1 seemed to increase with the duration of follow-up. However, it is still unclear whether the similar levels of soluble VCAM-1, ICAM-1, and P-selectin in CHD patients and controls are due to differences in the populations studied.

\section{Association Between Circulating Cell Adhesion \\ Molecules and the Extent of CHD}

Peter et al reported that soluble VCAM-1 levels, in contrast with soluble ICAM-1 and P-selectin levels, correlated with the extent of human atherosclerosis, as defined by the mean internal vessel surface area of the abdominal aorta and pelvic and leg arteries!2 Our findings of no association between soluble ICAM-1 or P-selectin levels and the extent of coronary atherosclerosis, as judged by the number of stenosed coronary arteries, are partly similar to those of Peter et al!' However, we did not observe a significant association between soluble VCAM-1 and the extent of coronary atherosclerosis.

\section{Influence of Serum Lipids, Lipoproteins and Apolipoproteins on Circulating Cell Adhesion Molecules}

As the levels of soluble adhesion molecules were not different between subjects with and without CHD, we studied the influence of serum levels of lipids, lipoproteins, and apolipoproteins on levels of soluble adhesion molecules in all of the subjects. We found that, after controlling for age, gender and BMI, levels of soluble VCAM-1 were inversely related to serum levels of $\mathrm{HDL}_{3}-\mathrm{C}$, apo A-II, and Lp A-I/A-II, soluble ICAM-1 levels were inversely related to serum levels of apo A-II and Lp A-I/A-II, and sPselectin levels were inversely related to serum Lp A-I levels. Our findings partly support those of Hwang et $\mathrm{al}^{31}$ and Ridker et $\mathrm{al}^{33}$ in that ICAM-1 was negatively associated with HDL-C, and may also be supported by reports that HDL inhibits both the adhesion of monocytes to endothelial cells ${ }^{34}$ and the expression of adhesion molecules on the surface of endothelial cells $s^{35}$

\section{Study Limitations}

In this angiographic case-control study, patients with $\mathrm{CHD}$ were not matched with controls with regard to gender (Table 1). We tried to avoid possible bias by adjusting for age and gender when comparing soluble adhesion molecules and lipid variables between patients with and without
CHD, as VCAM-1 was significantly correlated with age $(r=0.29, p<0.01)$ in all of the patients.

We selected angiographically defined normal subjects as controls. They had undergone diagnostic coronary angiography because of suspected or known coronary atherosclerosis or other reasons (mostly atypical chest pain). Patients with spastic angina pectoris were excluded from the controls and none of the controls had MI. However, a selection bias is known to exist: angiographically defined normal subjects generally have more risk factors for coronary disease than patients with clinical symptoms but who have not been selected for angiography, because a person with both a chest pain and a known risk factor, such as smoking, may be more likely to be referred for angiography than a person with just a clinical symptom? ${ }^{36}$ It is possible that the lack of differences in the levels of soluble adhesion molecules between subjects with and without CHD (Table 2) and the lack of an association between the levels of soluble adhesion molecules and the severity of coronary disease as judged by the number of involved vessels (Table 4) in the present study may be related to this bias. Previous angiographic studies, such as the Coronary Artery Surgery Study, have also failed to show associations between classic lipid risk factors and the severity of disease, presumably due to the biases involved in selecting patients for angiography. Thus, biases produced in selecting the controls may have limited the power of this study. Our results do not exclude the possibility that serum levels of soluble cell adhesion molecules may have some clinical value in discriminating CHD patients. Further studies are needed with normal healthy subjects who have no risk factors.

\section{Conclusions}

The serum levels of soluble VCAM-1, ICAM-1, and Pselectin were not related to CHD or the extent of coronary atherosclerosis. However, they were inversely related to serum levels of high-density lipoprotein-related lipoproteins.

\section{Acknowledgments}

This work was supported by grants-in-aid from the Ministry of Education, Science and Culture of Japan (Nos. 06670809, 07670827, 09670773, 10670693), by research grants from the Ministry of Health and Welfare, and by research grants from the Fukuoka University Research Fund.

\section{References}

1. Ross R: The pathogenesis of atheroscerosis: a perspective for the 1990s. Nature 1993; 362: $801-809$

2. Springer TA: Traffic signals for lymphocyte recirculation and leukocyte emigration: the multistep paradigm. Cell 1994; 76: $301-314$

3. Li H, Cybulsky MI, Gimbrone MA, Jr, Libby P: An atherogenic diet rapidly induces VCAM-1, a cytokine-regulatable mononuclear leukocyte adhesion molecule, in rabbit aortic endothelium. Arterioscler Thromb 1993; 13: 197-204

4. O'Brien KD, Allen MD, McDonald TO, Chait A, Harlan JM, Fishbein D, et al: Vascular cell adhesion molecule-1 is expressed in human coronary atherosclerotic plaques: Implications for the mode of progression of advanced coronary atherosclerosis [see comments]. J Clin Invest 1993; 92: 945-951

5. O'Brien KD, McDonald TO, Chait A, Allen MD, Alpers CE: Neovascular expression of E-selectin, intercellular adhesion molecule-1, and vascular cell adhesion molecule-1 in human atherosclerosis and their relation to intimal leukocyte content. Circulation 1996; 93: $672-682$

6. Cybulsky MI, Gimbrone MA Jr: Endothelial expression of a 
mononuclear leukocyte adhesion molecule during atherogenesis. Science 1991; 251: 788-791

7. Davies MJ, Gordon JL, Gearing AJ, Pigott R, Woolf N, Katz D, et al: The expression of the adhesion molecules ICAM-1, VCAM-1, PECAM, and E-selectin in human atherosclerosis. J Pathol 1993; 171: $223-229$

8. Johnson Tidey RR, McGregor JL, Taylor PR, Poston RN: Increase in the adhesion molecule P-selectin in endothelium overlying atherosclerotic plaques: Coexpression with intercellular adhesion molecule-1. Am J Pathol 1994; 144: 952-961

9. Pigott R, Dillon LP, Hemingway IH, Gearing AJ: Soluble forms of E-selectin, ICAM-1 and VCAM-1 are present in the supernatants of cytokine-activated cultured endothelial cells. Biochem Biophys Res Commun 1992; 187: 584-589

10. Leeuwenberg JF, Smeets EF, Neefjes JJ, Shaffer MA, Cinek T, Jeunhomme TM, et al: E-selectin and intercellular adhesion molecule-1 are released by activated human endothelial cells in vitro. Immunology 1992; 77: 543-549

11. Nakai K, Itoh C, Kawazoe K, Miura Y, Sotoyanagi H, Hotta K, et al: Concentration of soluble vascular cell adhesion molecule-1 (VCAM1) correlated with expression of VCAM-1 mRNA in the human atherosclerotic aorta. Coron Artery Dis 1995; 6: 497-502

12. Peter K, Nawroth P, Conradt C, Nordt T, Weiss T, Boehme M, et al: Circulating vascular cell adhesion molecule-1 correlates with the extent of human atherosclerosis in contrast to circulating intercellular adhesion molecule-1, E-selectin, P-selectin, and thrombomodulin. Arterioscler Thromb Vasc Biol 1997; 17: 505-512

13. Blann AD, McCollum CN: Circulating endothelial cell/leukocyte adhesion molecules in atherosclerosis. Thromb Haemost 1994; 72: $151-154$

14. Hackman A, Abe Y, Insull W Jr, Pownall H, Smith L, Dunn K, et al: Levels of soluble cell adhesion molecules in patients with dyslipidemia. Circulation 1996; 93: 1334-1338

15. Kaikita K, Ogawa H, Yasue H, Sakamoto T, Miyao Y, Suefuji H, et al: Increased plasma soluble intercellular adhesion molecule-1 levels in patients with acute myocardial infarction. Jpn Circ J 1997; 61: $741-748$

16. Shimomura H, Ogawa H, Arai H, Moriyama Y, Takazoe K, Hirai N, et al: Serial changes in plasma levels of soluble P-selectin in patients with acute myocardial infarction. Am J Cardiol 1998; 81: 397-400

17. Judkins MP: A percutaneous transfemoral technique. Radiology 1967; 89: $815-821$

18. Saku K, Jimi S, Sasaki N, Nii T, Shirai K, Koga N, et al: Reduced coronary vasodilation in patients with familial hypercholesterolemia following intracoronary injection of isosorbide dinitrate. Jpn Circ J 1995; 59: $808-814$

19. Allain CC, Poon LS, Chan CS, Richmond W: Enzymatic determination of total serum cholesterol. Clin Chem 1974; 29: 470-475

20. Bucolo G, David H: Quantitative determination of serum triglycerides by the use of enzymes. Clin Chem 1973; 19: 476-482

21. Noma A, Nezu-Nakayama K, Kita M, Okabe H: Simultaneous determination of serum cholesterol in high- and low-density lipoproteins with use of heparin $\mathrm{Ca}^{2+}$ and an anion-exchange resin. Clin Chem 1978; 24: $1504-1508$
22. Havel RJ, Eder HA, Bragdon JH: The distribution and chemical composition of ultracentrifugally separated lipoproteins in human serum. J Clin Invest 1955; 34: 1345-1353

23. Ikeda T, Shibuya U, Sugiuchi H, Araki S, Uji Y, Okabe H: Automated immunoturbidimetric analysis of six plasma apolipoproteins: correlation with radioimmunodiffusion assays. J Clin Lab Anal 1991; 5: $90-95$

24. Ikewaki K, Zech LA, Kindt M, Brewer HBJ, Rader DJ: Apolipoprotein A-II production rate is a major factor regulating the distribution of apolipoprotein A-I among HDL subclasses LpA-I and LpA-I: A-II in normolipidemic humans. Arterioscler Thromb Vasc Biol 1995; 15: 306-312

25. Ohta T, Hattori S, Murakami M, Nishiyama S, Matsuda I: Age- and sex-related differences in lipoproteins containing apoprotein A-I. Atherosclerosis 1989; 9: 90-95

26. Stampfer MJ, Sacks FM, Salvini S, Willett WC, Hennekens CH: A prospective study of cholesterol, apolipoproteins, and the risk of myocardial infarction. $N$ Engl J Med 1991; 325: 373-381

27. Ohta T, Saku K, Takata K, Nakamura R, Ikeda Y, Matsuda I: Different effects of subclasses of HDL containing apo A-I (LpA-I) on cholesterol esterification in plasma and net cholesterol efflux from foam cells. Arterioscler Thromb Vasc Biol 1995; 15: 956-962

28. SAS/STAT User's Guide, Version 6, 4th edn, Vol. 2. Cary, NC: SAS Institute Inc, 1990; 891-1456

29. SAS/STAT Software: Changes and Enhancements through Release 6.11. Cary, NC: SAS Institute Inc, 1996; 317-314

30. De Caterina R, Basta G, Lazzerini G, Dell'Omo G, Petrucci R, Morale M, et al: Soluble vascular cell adhesion molecule-1 as a biohumoral correlate of atherosclerosis. Arterioscler Thromb Vasc Biol 1997; 17: 2646-2654

31. Hwang SJ, Ballantyne CM, Sharrett AR, Smith LC, Davis CE, Gotto AM Jr, et al: Circulating adhesion molecules VCAM-1, ICAM-1, and E-selectin in carotid atherosclerosis and incident coronary heart disease cases: the Atherosclerosis Risk In Communities (ARIC) study. Circulation 1997; 96: 4219-4225

32. Frijns CJ, Kappelle LJ, van Gijn J, Nieuwenhuis HK, Sixma JJ, Fijnheer R: Soluble adhesion molecules reflect endothelial cell activation in ischemic stroke and in carotid atherosclerosis. Stroke 1997; 28: $2214-2218$

33. Ridker PM, Hennekens CH, Roitman Johnson B, Stampfer MJ, Allen $\mathrm{J}$ : Plasma concentration of soluble intercellular adhesion molecule 1 and risks of future myocardial infarction in apparently healthy men. Lancet $1998 ; 351: 88-92$

34. Maier JA, Barenghi L, Pagani F, Bradamante S, Comi P, Ragnotti G: The protective role of high-density lipoprotein on oxidized-lowdensity-lipoprotein-induced U937/endothelial cell interactions. Eur J Biochem 1994; 221: 35-41

35. Cockerill GW, Rye KA, Gamble JR, Vadas MA, Barter PJ: Highdensity lipoproteins inhibit cytokine-induced expression of endothelial cell adhesion molecules. Arterioscler Thromb Vasc Biol 1995; 15: $1987-1994$

36. Pearson TA, Derby AA: Should arteriographic case-control studies be used to identify causes of atherosclerotic coronary artery disease? [Invited Commentary] Am J Epidemiol 1991; 134: 123-128 